\title{
PENGARUH UKURAN PEMERINTAH DAERAH, PENDAPATAN ASLI DAERAH DAN BELANJA MODAL TERHADAP KINERJA KEUANGAN PEMERINTAH DAERAH
}

\author{
Ni Made Diah Permata Sari ${ }^{1}$ \\ I Ketut Mustanda ${ }^{2}$ \\ ${ }^{1,2}$ Fakultas Ekonomi dan Bisnis Universitas Udayana (Unud), Bali, Indonesia \\ E-mail:diahpsdiah@gmail.com
}

\begin{abstract}
ABSTRAK
Penelitian ini bertujuan untuk menguji dan menganalisis pengaruh ukuran pemerintah daerah, pendapatan asli daerah dan belanja modal terhadap kinerja keuangan pemerintah daerah di Kabupaten Badung periode 2013 - 2017. Teknik analisis data yang dipergunakan adalah analisis regresi linier berganda. Hasil analisis data menunjukkan bahwa ukuran pemerintah daerah berpengaruh negatif terhadap kinerja keuangan pemerintah daerah. Hal ini menunjukkan bahwa ukuran pemerintah daerah yang diproksikan dengan total aset yang dimiliki pemerintah daerah belum memberikan kontribusi terhadap kinerja keuangan pemerintah daerah. Pendapatan asli daerah berpengaruh positif terhadap kinerja keuangan pemerintah daerah. Hal ini menunjukkan semakin tinggi pendapatan asli daerah yang dihasilkan maka akan semakin tinggi pula kinerja keuangan pemerintah daerah. Dan belanja modal berpengaruh positif terhadap kinerja keuangan pemerintah daerah. Hal ini menunjukkan bahwa semakin tinggi belanja modal yang dilakukan pemerintah maka semakin tinggi pula kinerja keuangan pemerintah daerah.
\end{abstract}

Kata kunci: ukuran, PAD, belanja modal, kinerja keuangan

\begin{abstract}
This study aims to examine and analyze the effect of local government size, regional original income and capital expenditure on the financial performance of local governments in Badung Regency for the period 2013 - 2017. Data analysis techniques used are multiple linear regression analysis. The results of data analysis show that the size of the local government has a negative effect on the financial performance of local governments. This shows that the size of the local government that is proxied by the total assets owned by the local government has not contributed to the financial performance of the local government. Original regional income has a positive effect on the financial performance of local governments. This shows that the higher the local revenue generated, the higher the financial performance of the local government. And capital expenditure has a positive effect on the financial performance of local governments. This shows that the higher capital expenditure made by the government, the higher the financial performance of local governments.

Keywords: size, PAD, capital expenditure, financial performance
\end{abstract}


Ni Made Diah Permata Sari. Pengaruh Ukuran Pemerintah.....

\section{PENDAHULUAN}

Otonomi daerah adalah kebebasan yang dimiliki daerah untuk membuat peraturan daerah, menyusun, mengelola dan melaksanakan kebijakan serta keuangan daerahnya sendiri (Sujarweni, 2015:231). Diterapkannya kebijakan otonomi daerah disebabkan karena ketidakmampuan pemerintah pusat untuk mengurus keseluruhan pembangunan daerah, oleh karena itu pemerintah pusat melimpahkan wewenang dan kekuasaan kepada pemerintah daerah untuk mengelola dengan mandiri seluruh kepentingan daerahnya (Rosemarry et al., 2016). Penerapan kebijakan otonomi daerah menuntut pemerintah daerah untuk dapat mengelola keuangan daerah yang didapat melalui pemanfaatan potensi potensi daerah secara mandiri yang nantinya dipergunakan untuk pembangunan daerah. Halaskova dan Halaskova (2016) berpendapat bahwa seluruh potensi potensi yang dimiliki oleh daerah berpengaruh terhadap kualitas ruang lingkup pelayanan yang diberikan kepada masyarakat.

Pengelolaan keuangan merupakan salah satu faktor yang sangat penting yang harus dijalankan oleh setiap daerah di Indonesia. Pengelolaan keuangan daerah merupakan kunci penentu keberhasilan dan kesuksesan pembangunan serta penyelenggaraan pemerintah daerah. Dengan adanya pengelolaan keuangan daerah yang baik dan optimal akan menjamin tercapainya pembangunan dan penyelenggaraan pemerintah daerah yang nanti berdampak pada peningkatan kinerja pemerintah daerah. Sularso dan Restianto (2011) menjelaskan bahwa kemajuan suatu daerah dapat dilihat dari bagaimana daerah tersebut mengelola keuangannya. Pengelolaan kuangan daerah harus dilakukan secara efektif dan 
efisien berdasarkan prinsip yang ada, meliputi transparansi, value for money, dan akuntabilitas yang nantinya dapat mendorong terjadinya pertumbuhan ekonomi (Lucky, 2013).

Kemampuan pemerintah daerah dalam melakukan pengelolaan keuangan tercermin pada Anggaran Pendapatan dan Belanja Daerah (APBD) seperti kemampuan pemerintah dalam membiayai pembangunan dan meningkatkan pelayanan sosial kepada masyarakat serta mampu meningkatkan penerimaan pendapatan daerahnya (Rondonuwu dkk., 2015). Laporan Anggaran Pendapatan dan Belanja Daerah (APBD) masing - masing daerah dapat digunakan sebagai tolok ukur dalam proses pembangunan daerah. Pemerintah wajib melaporkan laporan pertanggungjawaban pengelolaan keuangan dalam menjalankan roda pemerintahan daerahnya kepada masyarakat guna tercapainya asas transparansi dari pelaporan tersebut masyarakat dapat menilai bagaimana kinerja pemerintah dalam mengelola keuangan daerahnya apakah sesuai dengan pendapatan yang diterima daerah dan apakah pengalokasiannya sesuai dengan kebutuhan masyarakatnya (Aziz, 2016).

Peraturan Menteri Dalam Negeri No. 21 Tahun 2011 Pasal 1 Ayat 37 (perubahan kedua dari Permendagri No. 13 Tahun 2006), kinerja adalah keluaran/hasil dari kegiatan/program yang akan atau telah dicapai sehubungan dengan penggunaan anggaran dengan kuantitas dan kualitas yang terukur. Kinerja keuangan merupakan indikator yang digunakan dalam menilai kinerja pemerintah daerah. Analisis kinerja keuangan dipergunakan untuk mengidentifikasi bagaimana alur keuangan pemerintah daerah berdasarkan laporan keuangan 
pemerintah daerah tersebut (Darwanis dan Saputra, 2014). Pengukuran kinerja keuangan pemerintah penting dilakukan mengingat pengaruhnya sangat besar terhadap sektor publik. Pengukuran kinerja keuangan juga dipergunakan sebagai cerminan dalam penilaian akuntabilitas serta kemampuan keuangan daerah dalam pelaksanaan otonomi daerah. Menurut Aziz (2016) faktor - faktor yang mempengaruhi kinerja keuangan pemerintah daerah yaitu ukuran pemerintah daerah, pendapatan asli daerah, dana perimbangan, belanja modal, pertumbuhan ekonomi, ukuran legislatif, dan leverage. Dalam penelitian ini faktor - faktor yang mempengaruhi kinerja keuangan pemerintah daerah yaitu ukuran pemerintah daerah, pendapatan asli daerah dan belanja modal.

Pengukuran kinerja menurut Halim (2008: 232) dapat diukur dengan membandingkan hasil yang dicapai dari satu periode dengan periode sebelumnya sehingga dapat diketahui bagaimana kecenderungan yang terjadi. Salah satu indikator yang dapat dipergunakan untuk menganalisis kinerja keuangan pemerintah daerah dalam mengelola keuangan daerahnya yaitu dengan menerapkan rasio keuangan terhadap $\mathrm{APBD}$, rasio yang dimaksud yaitu rasio kemandirian, rasio efisiensi, rasio pertumbuhan dan rasio efektifitas (Halim, 2008:230). Kinerja keuangan pemerintah daerah dalam penelitian ini dianalisis menggunakan rasio efektifitas. Pemerintah daerah merupakan pihak yang sangat berperan dalam mengelola keuangan daerah.

Kinerja keuangan pemerintah daerah Kabupaten Badung yang telah dianalisis menggunakan rasio efektifitas dari tahun ke tahun terus berfluktuasi. Tingkat keefektifan keuangan suatu daerah sangat dipengaruhi oleh perbandingan realisasi 
dengan target pendapatan asli daerah. Kinerja keuangan pemerintah daerah dapat dikatakan efektif jika realisasi pendapatan asli daerah lebih besar dari pada targetnya. Pertumbuhan pendapatan asli daerah mengalami kenaikan atau penurunan tergantung pada kemampuan daerah dalam menggali dan memanfaatkan sumber - sumber pendapatan.

Ukuran pemerintah daerah merupakan salah satu factor yang mempengaruhi kinerja keuangan pemerintah daerah, semakin besar ukuran pemerintah daerah maka semakin besar pula peluang kemudahan pemerintah daerah dalam melaksanakan kegiatan operasional dan roda pemerintahan daerah, begitu juga sebaliknya apabila ukuran pemerintah daerah kecil maka dalam pelaksanaan operasional dan roda pemerintahan daerah akan cenderung mengalami kesulitan, karena semakin besar ukuran pemerintah maka dapat memberi kelancaran dalam memperoleh pendapatan asli daerah (Aziz, 2016).

Ukuran pemerintah daerah dapat diproksikan dengan total aset yang dimiliki daerah tersebut. Agar dapat memberikan pelayanan yang optimal bagi masyarakatnya harus didukung oleh aset yang memadai. Pernyataan ini sejalan dengan penelitian yang dilakukan Maiyora dkk. (2015) bahwa ukuran pemerintah daerah berpengaruh positif terhadap kinerja keuangan, hal ini sejalan dengan penelitian yang dilakukan oleh Sari (2016), Aziz (2016), Ilmiyyah dkk. (2017), serta Alvini (2018). Artinya ukuran pemerintah daerah merupakan salah satu faktor yang harus diperhatikan untuk meningkatkan kinerja keuangan. Sedangkan penelitian lain yang dilakukan oleh Harumiati dan Payamta (2014), Mulyani dan Wibowo (2017), serta Nugroho dan Prasetyo (2017) menemukan hasil bahwa 
Ni Made Diah Permata Sari. Pengaruh Ukuran Pemerintah.....

ukuran pemerintah daerah berpengaruh negatif terhadap kinerja keuangan pemerintah daerah.

Semakin besar ukuran pemerintah daerah secara tidak langsung pendapatan asli daerah akan semakin besar pula, apabila pemerintah mampu memanfaatkan sumber - sumber potensi daerahnya serta mampu mengelola dengan baik seluruh potensi - potensi daerah (Mulyani dan Wibowo, 2017). Menurut Mohammed dan Salihu (2015) berpendapat bahwa pendapatan daerah merupakan komponen penting yang ada di daerah yang nantinya dipergunakan untuk membiayai seluruh program - program yang telah direncanakan oleh pemerintah. Pasal 157 Undang Undang No. 32 Tahun 2004 tentang Pendapatan, Belanja, dan Pembiayaan menyebutkan bahwa sumber pendapatan daerah terdiri atas pendapatan asli daerah yang selanjutnya disebut PAD yaitu hasil pajak daerah, hasil retribusi daerah, hasil pengelolaan kekayaan daerah yang dipisahkan dan lain - lain pendapatan asli daerah yang sah. Pendapatan asli daerah memberikan arti penting bagi daerah karena nantinya akan dapat dipergunakan untuk menjalankan roda pemerintahan guna menunjang kesejahteraan masyarakatnya (Andirfa dkk., 2016).

Semakin tinggi pendapatan asli daerah maka semakin tinggi pula kemampuan daerah untuk memenuhi kebutuhan dan meningkatkan pelayanan terhadap masyarakatnya apabila daerah mampu mengelola dengan baik. Kemampuan menggali dan memanfaatkan potensi - potensi yang dimiliki daerah secara optimal akan menghasilkan sumber pendapatan yang berasal dari pendapatan asli daerah (Sebastiana dan Cahyo, 2016). 
Penelitian yang dilakukan oleh Wenny (2012) menemukan hasil bahwa pendapatan asli daerah berpengaruh positif terhadap kinerja keuangan pemerintah daerah, hasil penelitian ini juga sejalan dengan penelitian yang dilakukan oleh Julitawati dkk. (2012), Harumiati dan Payamta (2014), Budianto dan Alexander (2016), Juwita (2016) serta Ayu (2018). Sedangkan penelitian lain yang dilakukan oleh Mulyani dan Wibowo (2017) menemukan hasil bahwa pendapatan asli daerah berpengaruh negatif terhadap kinerja keuangan pemerintah daerah, penelitian ini sejalan dengan penelitian yang dilakukan Machmud dan Radjak (2018).

Apabila pendapatan suatu daerah tinggi maka belanja untuk memenuhi kebutuhan roda pemerintahannya semakin tinggi pula (Antari dan Sedana, 2018). Belanja memiliki pengaruh terhadap kinerja keuangan pemerintah daerah (Bojanic, 2013). Belanja daerah sangat berkaitan erat dengan kualitas pelayanan publik yang akan diberikan daerah kepada masyarakatnya (Antari dan Sedana, 2018). Belanja daerah dapat dibedakan menjadi 2 yaitu belanja modal dan belanja administrasi (Udoka, 2015). Belanja yang telah dilakukan oleh pemerintah berfungsi sebagai kebijakan ekonomi yang nantinya berdampak pada perekonomian daerah (Menyah dan Rufael, 2013). Pendapat ini sejalan dengan hasil penelitian yang telah dilakukan oleh Aydin et al. (2016) dan Ayinde et al. (2015) yang memperoleh hasil bahwa jika belanja pemerintah dialokasikan secara tepat akan berpengaruh positif terhadap pertumbuhan ekonomi. Pendapat tersebut sejalan pula dengan penelitian yang dilakukan Amuka et al. (2016) yang menyatakan bahwa belanja pemerintah dapat menyebabkan terjadinya stabilitas pada perekonomian, dimana belanja yang dilakukan pemerintah daerah dalam pembangunan infrastruktur daerah akan 
Ni Made Diah Permata Sari. Pengaruh Ukuran Pemerintah.....

meningkatkan minat investor untuk melakukan investasi sehingga nantinya perekonomian daerah akan menjadi lebih maju. Chude dan Chude (2013) berpendapat bahwa belanja modal yang dilakukan pemerintah dapat meningkatkan taraf hidup masyarakat yang tergolong dalam kalangan bawah. Belanja juga dapat mempercepat pertumbuhan perekonomian (Nwosu dan Okafor, 2014).

Menurut Peraturan Pemerintah No. 24 Tahun 2005, belanja modal adalah pengeluaran yang dilakukan dalam rangka pembelian/ pengadaan aset tetap dan aset lainnya yang mempunyai masa manfaat lebih dari 12 bulan (dua belas bulan). Menurut Permendagri No. 13 Tahun 2016, belanja modal didefinisikan sebagai pengeluaran yang dilakukan dalam rangka pembelian/pengadaan atau pembangunan aset tetap berwujud yang mempunyai nilai manfaat lebih dari 12 (dua belas) bulan untuk digunakan dalam kegiatan pemerintah, seperti dalam bentuk tanah, peralatan dan mesin, gedung dan bangunan, jalan, irigasi, jaringan, dan aset tetap lainnya. Pesatnya perkembangan pembangunan dari alokasi belanja modal nantinya diharapkan terjadinya peningkatan kemandirian suatu daerah dalam memfasilitasi dan membiayai segala kegiatan daerah, terutama di bidang keuangan daerah (Darwanis dan Saputra, 2014). Belanja modal yang telah ditujukan untuk membiayai proyek - proyek bertujuan untuk meningkatkan kesejahteraan dan kepentingan masyarakatnya. Daerah yang memiliki entitas belanja modal yang lebih tinggi per kapita dibandingkan dengan pendapatan yang dihasilkan maka daerah tersebut harus melakukan penekanan dalam keuangannya (Brusca et al., 2015). Pernyataan tersebut sejalan dengan penelitian yang dilakukan oleh Badrudin 
(2011) yang berpendapat bahwa belanja modal berpengaruh positif terhadap kesejahteraan masyarakat.

Belanja modal pemerintah pada intinya akan membangun infrastruktur, sarana dan prasarana yang dibutuhkan oleh daerah guna menunjang pelayanan publik (Nugroho dan Rohman, 2012). Menurut Astiti dan Mimba (2016) alokasi dana belanja modal akan banyak membantu daerah untuk memperoleh sumber keuangan yang berasal dari potensi daerah yang nantinya dapat berkontribusi terhadap pertumbuhan pendapatan daerah, sehingga dapat berpengaruh terhadap peningkatan kinerja pemerintah daerah dan menurut Andirfa dkk. (2016) bahwa infrastruktur yang tersedia dengan baik diharapkan mampu menciptakan efisiensi di berbagai sektor, sehingga meningkatkan tingkat produktifitas masyarakat dan akan berimplikasi pada kinerja keuangan pemerintah daerah. Menurut Puspitasari dkk. (2015) pembangunan infrastruktur yang berupa pembangunan fasilitas umum yang signifikan dikatakan dapat mampu meningkatkan pertumbuhan kinerja pemerintah daerah.

Penelitian yang dilakukan oleh Harumiati dan Payamta (2014) menemukan hasil bahwa belanja modal berpengaruh positif terhadap kinerja keuangan pemerintah daerah, hal tersebut sejalan dengan hasil penelitian yang dilakukan oleh Astiti dan Mimba (2016), Andirfa dkk. (2016), Mulyani dan Wibowo (2017), serta Alvini (2018). Sedangkan penelitian lain yang dilakukan oleh Rohman dkk. (2015) dan Antari dan Sedana (2018) mendapatkan hasil bahwa belanja modal berpengaruh negatif terhadap kinerja keuangan daerah. 
Berdasarkan hasil penelitian sebelumnya terdapat perbedaan hasil penelitian yang didapat oleh peneliti - peneliti sebelumnya dan diindikasi terdapatnya research gap, yang menarik untuk diteliti kembali mengenai pengaruh ukuran pemerintah daerah, pendapatan asli daerah dan belanja modal terhadap kinerja keuangan pemerintah daerah dengan tujuan untuk memperjelas kembali temuan temuan peneliti sebelumnnya. Peneliti memilih Kabupaten Badung karena kinerja keuangan pemerintah daerah yang ditinjau dari rasio efektifitas dari tahun ke tahun terus berfluktuasi. Kabupaten Badung juga merupakan daerah yang memiliki ukuran pemerintah daerah yang paling besar di Provinsi Bali dengan total aset keseluruhan yang tinggi diikuti dengan tingkat pendapatan asli daerah yang paling tinggi dan tentunya tingkat belanja modal yang tinggi pula.

Ukuran pemerintah yang diproksikan dengan total aset yang dimilki daerah merupakan salah satu indikator dalam mengukur kemudahan kegiatan operasional daerah, semakin besar ukuran pemerintah daerah maka semakin besar pula kemudahan pemerintah daerah dalam melaksanakan kegiatan operasional dan roda pemerintahan daerah. Selain kemudahan di bidang operasional, ukuran pemerintah daerah yang besar memberikan kelancaran dalam memperoleh pendapatan asli daerah sehingga dapat meningkatkan realisasi pendapatan asli daerah dan nantinya akan berdampak pada peningkatan kinerja keuangan pemerintah daerah. Maka dari itu, semakin besar ukuran pemerintah daerah dengan pengelolaan yang optimal diharapkan menghasilkan kinerja yang semakin baik pula. Hal tersebut sejalan dengan hasil penelitian yang dilakukan sebelumnya yaitu menurut Maiyora dkk. (2015), Sari (2016), Aziz (2016), Ilmiyyah dkk. (2017), serta Alvini (2018) 
menemukan hasil bahwa ukuran pemerintah daerah berpengaruh positif terhadap kinerja keuangan

Berdasarkan uraian di atas maka hipotesis pertama yang diajukan sebagai berikut.

$\mathrm{H}_{1}$ : Ukuran pemerintah daerah berpengaruh positif terhadap kinerja keuangan pemerintah daerah di Kabupaten Badung.

Pendapatan asli daerah merupakan bagian penting dalam penerimaan daerah yang nantinya berperan dalam pembangunan daerah dalam rangka menunjang kesejahteraan masyarakat di daerahnya. Tingginya kemampuan daerah dalam menghasilkan pendapatan asli daerah nantinya akan disesuaikan dengan pembangunan daerah guna melengkapi kebutuhan masyarakat (Mahmudi, 2010:18).

Daerah yang memiliki kemampuan mengelola dengan optimal seluruh sumber - sumber potensi daerahnya akan dapat meningkatkan realisasi pendapatan asli daerah dan nantinya akan berdampak pada peningkatan kinerja keuangan pemerintah daerah. Menurut Darwanis dan Saputra (2014) berpendapat bahwa peningkatan pendapatan asli daerah yang bersumber dari pajak daerah, retribusi daerah, hasil pengelolaan kekayaan daerah yang dipisahkan dan lain lain pendapatan asli daerah yang sah akan berdampak pada peningkatan kinerja keuangan daerahnya. Penelitian tersebut sejalan dengan penelitian yang dilakukan oleh Wenny (2012), Julitawati dkk. (2012), Harumiati dan Payamta (2014), Budianto dan Alexander (2016), Juwita (2016) serta Ayu (2018) yang menemukan hasil bahwa pendapatan asli daerah berpengaruh positif terhadap kinerja keuangan pemerintah daerah. 
Berdasarkan uraian di atas maka hipotesis yang diajukan dalam penelitian ini adalah sebagai berikut.

$\mathrm{H}_{2}$ : Pendapatan asli daerah berpengaruh positif terhadap kinerja keuangan pemerintah daerah di Kabupaten Badung.

Menurut Peraturan Menteri Dalam Negeri Nomor 13 Tahun 2006, belanja modal merupakan kelompok dari belanja daerah, yang dapat diartikan sebagai pengeluaran yang dilakukan dalam rangka pembelian, pengadaan atau pembangunan aset tetap tak berwujud. Mohammed dan Salihu (2015) berpendapat bahwa belanja modal adalah belanja yang dilakukan oleh pemerintah daerah yang dapat meningkatkan aktiva tetap dan memberikan manfaat jangka panjang.

Peningkatan belanja modal mampu meningkatkan pertumbuhan ekonomi daerah sehingga akan berdampak pada peningkatan pendapatan asli daerah dan dengan adanya peningkatan tersebut secara tidak langsung realisasi pendapatan asli daerah akan meningkat pula. Pembangunan infrastruktur daerah berupa fasilitas umum adalah salah satu bentuk belanja modal yang menunjang pertumbuhan pendapatan. Menurut Puspitasari dkk. (2015) pembangunan infrastruktur yang berupa pembangunan fasilitas umum yang signifikan dikatakan dapat mampu meningkatkan kinerja keuangan pemerintah daerah. Hal tersebut sejalan dengan hasil penelitian yang dilakukan oleh Harumiati dan Payamta (2014), Astiti dan Mimba (2016), Andirfa dkk. (2016), Mulyani dan Wibowo (2017), serta Alvini (2018) menemukan hasil bahwa belanja modal berpengaruh yang positif terhadap kinerja keuangan pemerintah daerah.

Berdasarkan uraian di atas, maka hipotesis yang diajukan dalam penelitian ini adalah sebagai berikut. 
$\mathrm{H}_{3}$ : Belanja modal berpengaruh positif terhadap kinerja keuangan pemerintah daerah di Kabupaten Badung.

\section{METODE PENELITIAN}

Lokasi penelitian pada penelitian ini adalah di Kabupaten Badung karena adanya permasalahan berupa berfluktuasinya kinerja keuangan pemerintah daerah yang dianalisis menggunakan rasio efektifitas. Objek dalam penelitian ini adalah kinerja keuangan pemerintah daerah Kabupaten Badung pada periode 2013 - 2017. Kinerja keuangan pemerintah daerah dapat dianalisis menggunakan rasio efektifitas, dimana rasio efektifitas dapat dirumuskan sebagai berikut.

Rasio Efektifitas PAD $=\underline{\text { Realisasi Penerimaan PAD }} \times 100 \%$

\section{Target penerimaan PAD}

Dalam penelitian ini, ukuran pemerintah daerah diproksikan dengan total aset yang dimiliki oleh pemerintah daerah yang terdapat dalam neraca Kabupaten Badung periode 2013 - 2017 dengan data yang dipergunakan adalah data bulanan. Data total aset telah ditransformasikan ke dalam bentuk Logaritma Natural (Ln).

Data pendapatan asli daerah yang dipergunakan dalam penelitian ini adalah data pendapatan asli daerah yang terdapat dalam Laporan Realisasi APBD Kabupaten Badung periode 2013 - 2017 dengan data yang dipergunakan adalah data bulanan. Pendapatan asli daerah didapatkan dari pajak daerah, retribusi daerah, hasil pengelolaan kekayaan daerah yang dipisahkan dan lain - lain pendapatan daerah yang sah. Data pendapatan asli daerah telah ditransformasikan ke dalam bentuk Logaritma Natural (Ln).

Data belanja modal yang dipergunakan dalam penelitian ini adalah data realisasi belanja modal yang terdapat dalam Laporan Realisasi APBD Kabupaten 
Ni Made Diah Permata Sari. Pengaruh Ukuran Pemerintah.....

Badung periode 2013 - 2017 dengan data yang dipergunakan adalah data bulanan. Total belanja modal didapatkan dari belanja modal tanah, belanja modal peralatan dan mesin, belanja modal gedung dan bangunan, belanja modal jalan, irigasi dan jaringan serta belanja modal aset tetap lainnya. Data belanja modal telah ditransformasikan ke dalam bentuk Logaritma Natural (Ln).

Pengumpulan data pada penelitian inimenggunakan metode observasi non partisipan, jenis data yang dipergunakan adalah data kuantitatif dengan sumber data yaitu data sekunder. Teknik analisis data yang dipergunakan adalah regresi linier berganda dengan tujuan untuk mengetahui pengaruh variabel terikat dengan variabel bebas. Analisis data dilakukan dengan program SPSS versi 24. Formulasi persamaan regresi linier berganda pada penelitian ini dapat dirumuskan sebagai berikut.

$Y=\alpha+\beta_{1} X_{1}+\beta_{2} X_{2}+\beta_{3} X_{3}+\varepsilon$.

Keterangan :

$\mathrm{Y}=$ Kinerja keuangan pemerintah daerah

$\alpha \quad=$ Konstanta regresi

$\beta_{1}, \beta_{2}, \beta_{3} \quad=$ Koefisien regresi variabel bebas

$\mathrm{X}_{1} \quad=$ Ukuran pemerintah daerah

$\mathrm{X}_{2} \quad=$ Pendapatan asli daerah

X3 $=$ Belanja modal

$\varepsilon \quad=$ Tingkat kesalahan pengganggu (standar eror)

Penelitian ini menggunakan analisis regresi linier berganda yaitu untuk mengetahui pengaruh antara variabel bebas dengan variabel terikat yaitu pengaruh ukuran pemerintah daerah, pendapatan asli daerah, dan belanja modal terhadap kinerja keuangan pemerintah daerah. 


\section{HASIL DAN PEMBAHASAN}

Kabupaten Badung merupakan salah satu kabupaten yang terdapat di Provinsi Bali. Perkembangan pariwisata yang begitu pesat membuat wilayah Badung Selatan memiliki perekonomian yang lebih maju jika dibandingkan dengan Badung Utara dan Badung Tengah yang didominasi oleh sektor pertanian. Tetapi apabila dilihat secara umum sektor unggulan yaitu sektor pariwisata, pertanian dan industri kecil \& kerajinan rumah tangga mampu memberikan kontribusi terhadap pertumbuhan pendapatan daerah dan meningkatkan kondisi perekonomian di Kabupeten Badung.

Kondisi perekonomian suatu daerah dapat dipengaruhi oleh kemampuan pemerintah daerah dalam mengelola seluruh potensi yang ada di daerahnya sehingga berdampak terhadap pertumbuhan pendapatan daerah. Semakin tinggi pendapatan akan mempengaruhi tingkat belanja suatu daerah. Belanja daerah merupakan pengeluaran yang bertujuan untuk memenuhi segala kebutuhan untuk menunjang pelayanan publik yang diberikan pemerintah daerah kepada masyarakatnya.

Analisis statistik deskriptif adalah statistik yang berfungsi untuk menganalisis dengan mendeskripsikan data yang digunakan dalam penelitian. Data yang dianalisis menggunakan statistik deskriptif yaitu mean, standard deviation, nilai minimum dan nilai maksimum.

Berdasarkan Tabel 1. nilai rata - rata kinerja keuangan sebesar 0,5527 persen dengan standar deviasi sebesar 0,31567 berarti rata - rata penyimpangan kinerja keuangan pemerintah daerah sebesar 0,31567. Nilai minimum kinerja keuangan 
sebesar 0,07 persen yang dimiliki Kabupaten Badung pada bulan Januari 2013 sedangkan nilai maksimum dari kinerja keuangan yaitu sebesar 1,12 persen yang dimiliki Kabupaten Badung pada bulan Desember 2016.

Tabel 1.

Hasil Analisis Statistik Deskriptif

\begin{tabular}{lllll}
\hline & \multicolumn{1}{r}{ Ukuran PD } & \multicolumn{1}{c}{ PAD } & \multicolumn{1}{r}{ Belanja Modal } & Kinerja Keu \\
\hline $\mathbb{N}$ & 60 & 60 & 60 & 60 \\
Mean & 12.419 .274 .290 & 1.550 .267 .105 & 298.253 .568 .765 & 0,5527 \\
& $.594,00$ & $.021,22$ &, 85 & 0,31567 \\
Std. Deviation & 7.619 .104 .054 & 995.702 .095 & 293.259 .873 .193 & \\
& $.806,02$ & $.434,55$ &, 83 & 0,07 \\
Minimum & 5.577 .766 .539 & 135.512 .041 & $450.000,00$ & \\
& $.993,89$ & $.355,17$ & 1.241 .111 .664 .922 & \multirow{2}{*}{, 12} \\
Maximum & 27.317 .747 .013 & 4.172 .457 .395 &, 39 & \\
& $.725,60$ & $.825,25$ & &
\end{tabular}

Sumber: Data diolah, 2018

Berdasarkan tabel di atas nilai rata - rata ukuran pemerintah daerah sebesar Rp 12.419.274.290.594,00 dengan standar deviasi sebesar 7.619.104.054.806,02 berarti rata - rata penyimpangan ukuran pemerintah daerah sebesar 7.619.104.054.806,02. Nilai minimum ukuran pemerintah daerah sebesar $\mathrm{Rp}$ 5.577.766.539.993,89 yang dimiliki Kabupaten Badung pada bulan Januari 2013 sedangkan nilai maksimum yaitu sebesar 27.317.747.013.725,60 yang dimiliki Kabupaten Badung pada bulan November 2016.

Berdasarkan tabel di atas nilai rata - rata pendapatan asli daerah sebesar Rp 1.550.267.105.021,22 dengan standar deviasi sebesar 995.702.095.434,55 berarti rata - rata penyimpangan pendapatan asli daerah sebesar 995.702.095.434,55. Nilai minimum pendapatan asli daerah sebesar Rp 135.512.041.355,17 yang dimiliki Kabupaten Badung pada bulan Januari 2013 sedangkan nilai maksimum yaitu sebesar Rp 4.172.457.395.825,25 yang dimiliki Kabupaten Badung pada bulan Desember 2017. 
Berdasarkan tabel di atas nilai rata - rata belanja modal sebesar $\mathrm{Rp}$ 298.253.568.765,85 dengan standar deviasi sebesar 293.259.873.193,83 berarti rata - rata penyimpangan belanja modal sebesar 293.259.873.193,83. Nilai minimum belanja modal sebesar Rp 450.000,00 yang dimiliki Kabupaten Badung pada bulan Februari 2016, sedangkan nilai maksimum sebesar Rp 1.241.111.664.922,39 yang dimiliki Kabupaten Badung pada bulan Desember 2017.

Analisis regresi linier berganda dapat dipergunakan untuk mengetahui pengaruh variabel terikat dengan variabel bebas. Analisis data dilakukan dengan program SPSS 24. Analisis regresi linier berganda dalam penelitian ini dipergunakan untuk mengetahui kinerja keuangan pemerintah daerah di Kabupaten Badung. Hasil analisis regresi linier berganda pada penelitian ini dapat dilihat pada Tabel 2.

Tabel 2.

Hasil Analisis Regresi Linier Berganda

\begin{tabular}{ccrrrrrr}
\hline Variabel & B & $\begin{array}{c}\text { Std. } \\
\text { Error }\end{array}$ & Beta & T & sig. & Tolerance & VIF \\
\hline (Constant) & $-6,106$ & 0,945 & & $-6,463$ & 0,000 & & \\
Ln_X1 & $\mathbf{- 0 , 0 8 7}$ & 0,031 & $-0,153$ & $-2,845$ & 0,006 & 0,896 & 1,116 \\
Ln_X1 & $\mathbf{0 , 3 1 4}$ & 0,024 & 0,818 & 13,161 & 0,000 & 0,675 & 1,482 \\
Ln_X3 & $\mathbf{0 , 0 2 2}$ & 0,007 & 0,205 & 3,370 & 0,001 & 0,702 & 1,424 \\
\hline Sumber: Data diolah, 2018 & & & & &
\end{tabular}

Berdasarkan Tabel 2. persamaan analisis regresi linier berganda penelitian ini dapat dirumuskan sebagai berikut.

$$
Y=-6,106-0,087 X_{1}+0,314 X_{2}+0,022 X_{3}
$$

Persamaan regresi linier berganda diatas menunjukkan arah dari masingmasing pengaruh variabel bebas terhadap variabel terikat. Koefisien regresi dari variabel bebas yang memiliki tanda positif artinya bahwa adanya pengaruh searah terhadap variabel terikat sedangkan jika koefisien regresi dari variabel bebas 
Ni Made Diah Permata Sari. Pengaruh Ukuran Pemerintah.....

memiliki tanda negatif memiliki arti adanya pengaruh yang berlawanan arah terhadap variabel terikat. Berdasarkan persamaan analisis regresi linier berganda diatas, maka dapat dijelaskan sebagai berikut.

Nilai koefisien variabel ukuran pemerintah daerah bernilai negarif sebesar 0,087 menunjukkan bahwa apabila ukuran pemerintah daerah menurun sebesar satu persen menyebabkan kinerja keuangan pemerintah daerah menurun sebesar -0,087 persen dengan anggapan bahwa variabel lainnya konstan.

Nilai koefisien variabel pendapatan asli daerah bernilai positif sebesar 0,314 menunjukkan bahwa apabila pendapatan asli daerah meningkat sebesar satu persen menyebabkan kinerja keuangan pemerintah daerah meningkat sebesar 0,314 persen dengan anggapan bahwa variabel lainnya konstan.

Nilai koefisien variabel belanja modal bernilai positif sebesar 0,022 menunjukkan bahwa apabila belanja modal meningkat sebesar satu persen menyebabkan kinerja keuangan pemerintah daerah meningkat sebesar 0,022 persen dengan anggapan bahwa variabel lainnya konstan.

Uji kesesuaian model dilakukan untuk mengetahui apakah model penelitian yang telah memenuhi uji kesesuaian model. Jika nilai signifikan $>0,05$ maka hipotesis diterima (koefisien regresi tidak signifikan), ini berarti bahwa secara silmutan variabel bebas tersebut tidak berpengaruh signifikan terhadap variabel terikat. Jika nilai siginifikan $<0,05$ maka hipotesis ditolak (koefisien regresi signifikan). Ini berarti secara simultan variabel bebas tersebut berpengaruh signifikan terhadap variabel terikat. Hasil dari uji F dapat dilihat pada Tabel 3. 
Tabel 3.

Hasil Uji Kelayakan Model (Uji F)

\begin{tabular}{lccccc}
\hline Model & $\begin{array}{c}\text { Sum of } \\
\text { Squares }\end{array}$ & Df & $\begin{array}{c}\text { Mean } \\
\text { Square }\end{array}$ & F & Sig. \\
\hline Regression & 4,161 & 3 & 1,387 & 109,372 & $\mathbf{0 , 0 0 0}^{\mathbf{a}}$ \\
Residual & 0,710 & 56 & 0,013 & & \\
Total & 4,871 & 59 & & & \\
\hline
\end{tabular}

Sumber: Data diolah, 2018

Berdasarkan Tabel 3 di atas, nilai signifikansi uji kesesuaian model (Uji F) sebesar 0,000 atau $<0,05$ maka menunjukkan bahwa variabel bebas yang digunakan yaitu variabel ukuran pemerintah daerah, pendapatan asli daerah dan belanja modal berpengaruh signifikan secara simultan terhadap kinerja keuangan pemerintah daerah.

Koefisien determinasi digunakan untuk mengukur seberapa besar variabel bebas mampu menjelaskan variabel terikatnya yaitu ukuran pemerintah daerah, pendapatan asli daerah dan belanja modal terhadap kinerja keuangan pemerintah daerah. Hasil dari uji koefisien determinasi $\left(\mathrm{R}^{2}\right)$ dapat dilihat pada Tabel 4.

Tabel 4.

Hasil Uji Koefisien Determinasi $\left(\mathbf{R}^{2}\right)$

\begin{tabular}{lccc}
\hline Model & $\mathbf{R}$ & R Square & Adjusted R Square \\
\hline 1 & $0,924^{\mathrm{a}}$ & $\mathbf{0 , 8 5 4}$ & 0,846 \\
\hline Sumber: $:$ Data diolah, 2018 & &
\end{tabular}

Berdasarkan Tabel 4. di atas analisis regresi yang digunakan adalah analisis regresi linier berganda sehingga koefisien determinasi yang digunakan adalah $R$ Square. Nilai koefisien yang diperoleh adalah sebesar 0,854 . Nilai determinasinya menjadi $0,854 \times 100 \%=85,4 \%$. Hal ini mengindikasikan bahwa kinerja keuangan pemerintah daerah dijelaskan $85,4 \%$ oleh variabel ukuran pemerintah daerah, pendapatan asli daerah dan belanja modal sisanya dijelaskan oleh variabel lain yang tidak dimasukkan ke dalam model. 
Uji parsial (uji t) dipergunakan untuk menguji pengaruh masing-masing variabel bebas terhadap variabel terikat secara parsial. Pada penelitian ini, jika masing - masing koefisien signifikansi dari variabel bebas memiliki nilai lebih kecil dari 5\% $(0,05)$ yang ditetapkan sebagai derajat kepercayaan, maka dari itu, dapat disimpulkan bahwa variabel bebas secara parsial berpengaruh signifikan terhadap variabel terikat. Hasil dari uji parsial atau uji t dapat dilihat pada Tabel 5.

Tabel 5.

Hasil Uji Parsial atau Uji t

\begin{tabular}{cc}
\hline Variabel & sig. \\
\hline (Constant) & 0,000 \\
Ln_X1 & 0,006 \\
Ln_X2 & 0,000 \\
Ln_X3 & 0,001 \\
\hline
\end{tabular}

Sumber : Data diolah, 2018

Setelah diuji secara parsial dengan menggunakan uji t, diperoleh nilai sig. sebesar 0,006. Nilai sig. ini lebih kecil dari 0,05 sehingga dapat disimpulkan bahwa variabel ukuran pemerintah daerah memiliki pengaruh signifikan terhadap kinerja keuangan pemerintah daerah.

Setelah diuji secara parsial dengan menggunakan uji t, diperoleh nilai sig. sebesar 0,000. Nilai sig. ini lebih kecil dari 0,05 sehingga dapat disimpulkan bahwa variabel pendapatan asli daerah memiliki pengaruh signifikan terhadap kinerja keuangan pemerintah daerah.

Setelah diuji secara parsial dengan menggunakan uji t, diperoleh nilai sig. sebesar 0,001. Nilai sig. ini lebih kecil dari 0,05 sehingga dapat disimpulkan bahwa variabel belanja modal memiliki pengaruh signifikan terhadap kinerja keuangan pemerintah daerah. 
Hasil penelitian ini menunjukkan bahwa ukuran pemerintah daerah berpengaruh negatif terhadap kinerja keuangan pemerintah daerah di Kabupaten Badung periode 2013 - 2017. Hasil ini dapat dilihat pada Tabel 2. yang menunjukkan bahwa nilai koefisien B -0,087 yang menunjukkan pengaruh negatif. Dari hasil tersebut artinya bahwa ukuran pemerintah daerah berpengaruh negatif terhadap kinerja keuangan pemerintah daerah di Kabupaten Badung.

Ukuran pemerintah daerah yang diproksikan dengan total aset yang dimiliki daerah berpengaruh negatif disebabkan karena terjadinya perubahan dalam penilaian harga tanah di Kabupaten Badung yaitu pada bulan Januari 2013 sampai bulan November 2016 pemerintah daerah menggunakan penilaian tanah dengan pendekatan nilai pasar setelah dikoreksi oleh BPK penilaian harga tanah pada bulan Desember 2016 sampai bulan Desember 2017 berdasarkan NJOP, hal tersebut menyebabkan total aset yang dimiliki sangat berfluktuasi. Berubahnya penilaian harga tanah dari menggunakan pendekatan nilai pasar ke NJOP sangat berpengaruh terhadap kinerja keuangan pemerintah daerah di Kabupaten Badung periode 2013 2017.

Hasil yang diperoleh dalam penelitian ini, sejalan dengan hasil penelitian yang dilakukan sebelumnya yaitu Harumiati dan Payamta (2014), Mulyani dan Wibowo (2017), serta Nugroho dan Prasetyo (2017) menemukan hasil bahwa ukuran pemerintah daerah berpengaruh negatif terhadap kinerja keuangan pemerintah daerah.

Hasil penelitian ini menunjukkan bahwa pendapatan asli daerah berpengaruh positif terhadap kinerja keuangan pemerintah di Kabupaten Badung periode 2013 
Ni Made Diah Permata Sari. Pengaruh Ukuran Pemerintah.....

- 2017. Hasil ini dapat dilihat pada Tabel 2 yang menunjukkan bahwa nilai koefisien B sebesar 0,314 yang menunjukkan nilai positif yang berarti bahwa pendapatan asli daerah berpengaruh positif terhadap kinerja keuangan pemerintah daerah di Kabupaten Badung periode 2013 - 2017. Artinya semakin tinggi pendapatan asli daerah maka kinerja keuangan akan semakin meningkat pula.

Pendapatan asli daerah memberikan arti penting bagi daerah karena nantinya akan dapat dipergunakan untuk menjalankan roda pemerintahan guna menunjang kesejahteraan masyarakatnya. Peningkatan penerimaan pendapatan asli daerah yang tinggi setiap tahunnya menunjukkan tingginya sumber keuangan daerah. Jika sumber keuangan dapat dimanfaatkan dengan optimal maka dapat meningkatkan kinerja keuangan pemerintah daerah. Penelitian tersebut sejalan dengan penelitian yang dilakukan oleh Wenny (2012), Julitawati dkk. (2012), Harumiati dan Payamta (2014), Budianto dan Alexander (2016), Juwita (2016) serta Ayu (2018) yang menemukan hasil bahwa pendapatan asli daerah berpengaruh positif terhadap kinerja keungan pemerintah daerah.

Hasil penelitian ini menunjukkan bahwa belanja modal berpengaruh positif terhadap kinerja keuangan pemerintah daerah di Kabupaten Badung periode 2013 2017. Hasil ini dapat dilihat pada Tabel 2 yang menunjukkan bahwa nilai koefisien B sebesar 0,022 yang menunjukkan nilai positif yang berarti bahwa belanja modal berpengaruh positif terhadap kinerja keuangan pemerintah daerah di Kabupaten Badung. Artinya semakin tinggi belanja modal yang dilakukan pemerintah maka semakin tinggi pula kinerja keuangan pemerintah daerah. 
Belanja daerah sangat berkaitan erat dengan kualitas pelayanan publik yang akan diberikan daerah kepada masyarakatnya. Belanja modal yang telah ditujukan untuk membiayai proyek - proyek bertujuan untuk meningkatkan kesejahteraan masyarakatnya. Belanja modal pemerintah pada intinya akan membangun infrastruktur, sarana dan prasarana yang dibutuhkan oleh daerah guna menunjang pelayanan publik. Hal tersebut sejalan dengan hasil penelitian yang dilakukan oleh Harumiati dan Payamta (2014), Astiti dan Mimba (2016), Andirfa dkk. (2016), Mulyani dan Wibowo (2017), serta Alvini (2018) menemukan hasil bahwa belanja modal berpengaruh yang positif terhadap kinerja keuangan pemerintah daerah.

Hasil penelitian ini menunjukkan bahwa ukuran pemerintah daerah berpengaruh negatif terhadap kinerja keuangan pemerintah daerah di Kabupaten Badung hal ini disebabkan karena terjadinya perubahan dalam penilaian aset khususnya aset tanah sehingga berdampak pada kinerja keuangan pemerintah daerah di Kabupaten Badung.

Pendapatan asli daerah berpengaruh positif terhadap kinerja keuangan pemerintah daerah di Kabupaten Badung. Besarnya pendapatan asli daerah yang diterima Kabupaten Badung memberikan dampak terhadap peningkatan kinerja keuangan pemerintah daerah di Kabupaten Badung.

Sedangkan belanja modal berpengaruh positif terhadap kinerja keuangan pemerintah daerah di Kabupaten Badung. Belanja modal yang tinggi yang dimiliki Kabupaten Badung memberikan dampak terhadap terhadap peningkatan kinerja keuangan pemerintah daerah di Kabupaten Badung.

\section{SIMPULAN}


Ni Made Diah Permata Sari. Pengaruh Ukuran Pemerintah.....

Ukuran pemerintah daerah berpengaruh negatif terhadap kinerja keuangan pemerintah daerah di Kabupaten Badung. Hasil ini memberikan arti bahwa ukuran pemerintah daerah yang diproksikan oleh total aset yang dimiliki daerah Kabupaten Badung tidak memberikan kontribusi terhadap peningkatan kinerja keuangan pemerintah daerah periode 2013 - 2017.

Pendapatan asli daerah berpengaruh positif terhadap kinerja keuangan pemerintah daerah Kabupaten Badung. Hasil ini memberikan arti bahwa pendapatan asli daerah yang dihasilkan mampu memberikan kontribusi terhadap peningkatan kinerja keuangan pemerintah daerah periode 2013 - 2017.

Belanja modal berpengaruh positif terhadap kinerja keuangan pemerintah daerah Kabupaten Badung. Hasil ini memberikan arti bahwa belanja modal yang dihasilkan mampu memberikan kontribusi terhadap peningkatan kinerja keuangan pemerintah daerah periode 2013 - 2017.

Bagi pemerintah daerah, pendataan aset daerah harus dilaksanakan secara kontinu, agar nantinya seluruh aset yang dimiliki pemerintah daerah dapat tercatat sesuai dengan nilainya. Begitu pula dengan pendataan aset khususnya aset yang berupa tanah harus dilaksanakan secara kontinu pula menurut metode penilaian yang telah di tetapkan oleh BPK. Sehingga peneliti selanjutnya dapat memperoleh hasil penelitian yang nyata berdasarkan pada jumlah aset yang dimiliki pemerintah daerah.

Bagi pemerintah daerah, kemampuan dalam meningkatkan pendapatan asli daerah perlu dipertahankan dan ditingkatkan kembali karena dapat meningkatkan penerimaan daerah, dari hal tersebut diharapkan kinerja keuangan daerah dapat 
meningkat. Begitu juga dengan belanja modal perlu dipertahankan dan ditingkatkan kembali karena semakin besar belanja modal maka akan semakin banyak pembangunan infrastruktur dan sarana di daerah yang dapat meningkatkan pertumbuhan ekonomi.

Bagi peneliti selanjutnya sebaiknya menggunakan rasio keuangan terhadap APBD lainnya untuk mengukur kinerja keuangan pemerintah daerah seperti rasio kemandirian, rasio efisiensi, dan rasio pertumbuhan. Peneliti selanjutnya juga diharapkan untuk tidak hanya menggunakan satu kabupaten saja, melainkan juga menggunakan kabupaten - kabupaten lain yang ada di Provinsi Bali.

\section{REFERENSI}

Alvini, Yevi. (2018). Pengaruh Ukuran Pemerintah Daerah, Tingkat Kekayaan Daerah, Tingkat Ketergantungan Daerah Kepada Pemerintah Pusat dan Belanja Modal Terhadap Kinerja Keuangan Pemerintah Daerah (Studi pada Kabupeten/Kota se- Provinsi Riau Periode (2011)-(2016)). JOM $F E B, 1$ (1), hal.1-15.

Amuka, Joseph I., Miracle O. Ezeoke., dan Fredrick O. Asogwa. (2016). Government Spending Pattern and Macroeconomic Stability: A Vector Autoregressive Model. International Journal of Economics and Financial Issues, 6 (4), pp : 1930-1936.

Andirfa, Mulia., Hasan Basri., dan M. Shabri A. Majid. (2016). Pengaruh Belanja Modal, Dana Perimbangan, dan Pendapatan Asli Daerah Terhadap Kinerja Keuangan Kabupaten dan Kota di Provinsi Aceh. Jurnal Magister Akuntansi Pascasarjana Universitas Syiah Kuala, 5 (3), hal.30-38.

Antari, Ni Putu Gina Sukma dan Ida Bagus Panji Sedana. (2018). Pengaruh Pendapatan Asli Daerah dan Belanja Modal Terhadap Kinerja Keuangan Pemerintah Daerah. E-Jurnal Manajemen Unud, 7 (2), hal.1080-1110.

Astiti, Desak Nyoman Yulia dan Ni Putu Sri Harta Mimba. (2016). Pengaruh Belanja Rutin dan Belanja Modal pada Kinerja Keuangan Pemerintah Daerah. E-Jurnal Akuntansi Universitas Udayana, 14 (3), hal.1924-1950. 
Aydin, Celil., Merter Akıncı., dan Omer Y1lmaz. (2016). The Analysis of Visible Hand of Government : The Threshold Effect of Governmnet Spending on Economic Growth. International Journal of Trade Economics and Finance, 7 (5), pp : 170-178.

Ayinde, Kayode., John Kuranga., dan Adewale F. Lukman. (2015). Modeling Nigerian Government Expenditure, Revenue and Economic Growth: CoIntergration, Error Corecction Mechanism and Combined Estimators Analysis Approach. Asian Economic and Financial Review, 5 (6), pp : 858-867.

Ayu, Putri Puspita. (2018). Analisis PAD dan Dana Perimbangan Terhadap Kinerja Keuangan Pemda se- Jawa Barat. Jurnal Akuntansi \& Ekonomi, 3 (1), hal.80-96.

Aziz, Asmaul. (2016). Pengaruh Karakteristik Pemerintah Daerah Terhadap Kinerja Keuangan Pemerintah Daerah (Studi pada Pemerintah Daerah Kabupaten/ Kota di Jawa Timur). EKSIS, 11 (1), hal.86-101.

Badrudin, Rudy. (2011). Effect of Fiscal Decentralization on Capital Expenditure, Growth, and Welfare. Economic Journal of Emerging Markets, 3 (3), pp : 211-223.

Bojanic, Antonio N. (2013). The Composition of Government Expenditure and Economic Growth in Bolivia. Journal of Economic, 50 (1), pp : 83-105.

Brusca, Isabel., Francesca Manes Rossi., dan Natalia Aversano. (2015). Drivers for The Financial Condition of Local Government: A Comparative Study Between Italy and Spain. Journal of Local Self-Government, 13 (2), pp : 161-184.

Budianto dan Stanly W Alexander. (2016). Pengaruh PAD dan Dana Perimbangan Terhadap Kinerja Keuangan Pemerintah Kabupaten/Kota di Provinsi Sulawesi Utara. JURNAL EMBA, 4 (4), hal.844-851.

Chude, Nkiru Patricia dan Daniel Izuchukwu Chude. (2013). Impact of Government Expenditure on Economic Growth in Nigeria. International Journal of Business and Management Review, 1 (4), pp : 64-71.

Darwanis dan Ryanda Saputra. (2014). Pengaruh Belanja Modal Terhadap Pendapatan Asli Daerah dan Dampaknya pada Kinerja Keuangan Pemerintah Daerah. Jurnal Dinamika Akuntansi dan Bisnis, 1 (2), hal.183199.

Halaskova, Martina dan Renata Halaskova. (2016). Assessment of Financial Capabilities of Local Governments in EU Countries for the Development 
of Local Publik Services. Journal of Local Self-Government, 14 (3), pp : 379-397.

Halim, Abdul. (2008). Akuntansi Keuangan Daerah. Jakarta: Salemba Empat.

-----. (2014). Manajemen Keuangan Sektor Publik. Jakarta: Salemba Empat.

Halim, Abdul dan M. S. Kusufi. (2016). Teori, Konsep, dan Aplikasi Akuntansi Sektor Publik. Jakarta: Salemba Empat.

Harumiati, Yayuk dan Payamta. (2014). Pengaruh Karakteristik Pemerintah Daerah dan Temuan Audit BPK Terhadap Kinerja Pemerintah Daerah Kabupaten/Kota di Indonesia Tahun Anggaran (2011). ASSETS: Jurnal Akuntansi dan Pendidikan, 3 (2), hal.75-87.

Ilmiyyah., Nyanyu Miftahul dan Evada Dewata. (2017). Faktor- Faktor yang Mempengaruhi Kinerja Keuangan Pemerintah Kabupeten/Kota di Provinsi Sumatera Selatan Tahun (2012)-(2015). Jurnal Akuntansi, Ekonomi dan Manajemen Bisnis, 5 (1), hal.147-162.

Julitawati, Ebit., Darwanis., dan Jalaluddin. (2012). Pengaruh Pendapatan Asli Daerah (PAD) dan Dana Perimbangan Terhadap Kinerja Keuangan Pemerintah Kabupaten/Kota di Provinsi Aceh. Jurnal Akuntansi, 1 (1), hal.15-29.

Juwita, Rakhmini. (2016). Pengaruh Pendapatan Asli Daerah Terhadap Kinerja Keuangan Daerah (Studi Kasus pada Kabupaten/Kota di Provinsi Banten Tahun (2012)- (2015)). SEMNAS FEKOM, 1 (1), hal.608-616.

Lucky, Dihan. (2013). Analysis Of The Effect Of Regional Financial Performance To Economic Growth and Poverty Through Capital Expenditure (Case study of 38 Regencies/Cities in East Java Province). Journal of Economics and Sustainable Development, 4 (19), pp : 7-17.

Maiyora, Gita., Yusralini., dan Riska Natariasari. (2015). Pengaruh Karakteristik Pemerintah Daerah Terhadap Kinerja Keuangan Pemerintah Daerah Kabupaten/Kota (Studi Empiris Kabupaten/ Kota Di Pulau Sumatera). Jom FEKOM, 2 (2), hal.1-15.

Menyah, Kojo dan Yemane Wolde-Rufael. (2013). Government Expenditure and Economic Growth: The Ethiopian Experience, 1950-2007. The Journal of Developing Areas, 47 (1), pp : 263-280.

Mohammed., Ahmed dan Salihu. (2015). Expenditure and Internally Generated Revenue Relationship: An Analysis of Local Governments in Adamawa State, Nigeria. Journal of Arts, Science \& Commerce, 6 (3), pp : 67-77. 
Machmud, Joice dan Lukfiah Irwan Radjak. (2018). Pendapatan Asli Daerah, Dana Alokasi Umum dan Dana Alokasi Khusus Terhadap Kinerja Keuangan Pemerintah Kabupaten Gorontalo. Journal Of Accounting Science, 2 (1), hal.17-32.

Mulyani, Sri dan Hardiyanto Wibowo. (2017). Pengaruh Belanja Modal, Ukuran Pemerintah Daerah, Intergovernmental Revenue dan Pendapatan Asli Daerah Terhadap Kinerja Keuangan. Kompartemen, 15 (1), hal.57-66.

Nugroho, Fajar dan Abdul Rohman. (2012). Pengaruh Belanja Modal Terhadap Pertumbuhan Kinerja Keuangan Daerah dengan Pendapatan Asli Daerah Sebagai Variabel Intervening. Diponegoro Journal of Accounting, 1 (2), hal.1-14.

Nugroho, Tatas Ridho dan Novi Eko Prasetyo. (2017). Pengaruh Karakteristik Pemerintah Daerah Terhadap Kinerja Keuangan Pemerintah Daerah Kabupaten dan Kota di Jawa Timur. ASSETS Jurnal Akuntansi dan Pendidikan, 7 (1), hal.27-34.

Nwosu, Damian C dan Harrison O. Okafor. (2014). Government Revenue and Expenditure In Nigeria : A Disaggregated Analysis. Asian Economic and Financial Review, 4 (7), pp : 877-892.

Peraturan Menteri Dalam Negeri No. 21 Tahun (2011) Pasal 1 Ayat 37 (Perubahan Kedua Dari Permendagri No. 13 Tahun (2006)) tentang Pedoman Pengelolaan Keuangan Daerah. 23 Mei (2011). Lembaran Negara Republik Indonesia Tahun (2011) Nomor 310. Jakarta.

Peraturan Menteri Dalam Negeri Nomor 13 Tahun (2006) tentang Pedoman Pengelolaan Keuangan Daerah. 15 Mei (2006). Jakarta.

Peraturan Pemerintah Republik Indonesia Nomor 58 Tahun (2005) tentang Pengelolaan Keuangan Daerah. 9 Desember (2005). Lembaran Negara Republik Indonesia Tahun (2005) Nomor 140. Jakarta.

Peraturan Pemerintah Nomor 24 Tahun (2005) tentang Standar Akuntansi Permerintahan. 13 Juni (2005). Lembaran Negara Republik Indonesia Tahun (2005) Nomor 49. Jakarta.

Puspitasari, N.L.P. Lindri., M. Pradana Adiputra., dan N.L.G. Erni Sulindawati. (2015). Pengaruh Belanja Modal Terhadap Pertumbuhan Kinerja Keuangan Daerah dengan Pendapatan Asli Daerah Sebagai Variabel Intervening. E-Journal S1 AK Universitas Pendidikan Ganesha, 3 (1). hal.1-10 
Rohman, Abdul., Afif Fatri Pratama., dan Ahmad Royhaan. (2015). Pengaruh Belanja Modal dan Transfer Terhadap Kinerja Keuangan Pemerintah Kabupeten/Kota. JEMASI, 11 (2), hal.157-170.

Rondonuwu, Ritno H., Jantje J. Tinangon., dan Novi Budiarso. (2015). Analisis Efisiensi dan Efektifitas Pengelolaan Keuangan Daerah pada Dinas Pendapatan Daerah Kabupaten Minahasa. Jurnal EMBA, 3 (4), hal.23-32.

Rosemary., Chinyeaka Justine., dan Barisua Barry. (2016). Local Government Financial Autonomy: A Comparative Analysis of Nigeria and Brazil. Arabian Journal OF Bussiness and Management Review (OMAN Chapter), 5 (10), pp : 38-54.

Sari, Indah Puspita. (2016). Pengaruh Ukuran Pemerintah Daerah, PAD, Leverage, Dana Perimbangan dan Ukuran Legislatif Terhadap Kinerja Keuangan Pemerintah Daerah (Studi Pada Kab/Kota Pulau Sumatra). JOM Fekon, 3 (1), hal.679-692.

Sebastiana dan Herman Cahyo. (2016). Analysis of Economic Performance as the Independence Indicators of Government in East Java Province. Review of Integrative Business \& Economics Research, 5 (2), pp : 272-285.

Sujarweni, Wiratna. (2015). Akuntansi Sektor Publik. Yogyakarta:Penerbit Pustaka Baru Press.

Sularso, Havid dan Yanuar E. Restianto. (2011). Pengaruh Kinerja Keuangan Terhadap Alokasi Belanja Modal dan Pertumbuhan Ekonomi Kabupaten/Kota di Jawa Tengah. Media Riset Akuntansi, 1 (2), hal.109124.

Udoka, Chris O. (2015). The Effect of Public Expenditure on the Growth and Development of Nigerian Economy (1980-(2012)). International Review of Management and Business Research, 4 (3), pp : 823-833.

Wenny, Cherrya Dhia. (2012). Analisis Pengaruh Pendapatan Asli Daerah (PAD) Terhadap Kinerja Keuangan Pemerintah Kabupaten dan Kota di Provinsi Sumatera Selatan. Jurnal Ilmiah STIE MDP, 2 (1), hal.39-51. 